Karolina ZIELIŃSKA

University of Warsaw, Poland

\title{
Development Diplomacy. Development Aid as a Part of Public Diplomacy in the Pursuit of Foreign Policy Aims: Theoretical and Practical Considerations
}

\author{
Dyplomacja rozwojowa. \\ Pomoc rozwojowa jako część dyplomacji publicznej \\ w dążeniu do celów polityki zagranicznej: \\ aspekty teoretyczne i praktyczne
}

\section{- Abstrakt •}

Artykuł ten ma dwa cele. Po pierwsze, podejmuje próbę zdefiniowania koncepcji dyplomacji rozwojowej (czyli dyplomacji realizowanej za pośrednictwem pomocy rozwojowej) jako części dyplomacji publicznej, realizującej swoje cele dzięki zasobom miękkiej siły. Artykuł przywołuje i podejmuje refleksję nad wybranymi źródłami teoretycznymi w celu sformułowania wizji dyplomacji rozwojowej w dyplomacji publicznej. Po drugie, artykuł koncentruje się na praktycznej roli dyplomacji rozwojowej w kontekście celów polityki zagranicznej. Po teoretycznej refleksji nad tą kwestią następuje przestawienie przykładów praktycznych: dokumentów, działań oraz dotyczących ich badań, w których wystąpiło powiązanie między pomocą rozwojową a celami polityki zagranicznej. Prowadzi to do wniosków w sprawie strony praktycznej i efektywności włączania pomocy rozwojowej w ramy dyplomacji publicznej, a tym samym i polityki zagranicznej.

\section{- Abstract •}

This article's aims are twofold. Firstly, it endeavours to define the concept of development diplomacy (that is, diplomacy done through development aid) as a part of public diplomacy that realises its aims thanks to soft power resources. Several theoretical sources are recalled and reflected upon in order to come up with a vision of the role of development diplomacy within public diplomacy. Secondly, this article focuses on the role of development diplomacy in the context of the foreign policy aims. Theoretical reflection on this issue is followed by illustrative examples of documents, actions and research, where practical linkages between development aid and foreign policy' aims where made. It leads to conclusions regarding the practicalities and effectiveness of embracing development aid under the public diplomacy and thus also under foreign policy umbrella. 
Słowa kluczowe: pomoc rozwojowa, dyplomacja publiczna, polityka zagraniczna, miękka siła
Keywords: development aid, public diplomacy, foreign policy, soft power

\section{Introduction}

Programmes of aid extended towards less affluent countries are increasingly considered not only an expression of goodwill, way of reaching new markets or a form of intervention, but also in the context of promotion of a positive image of states donating aid. This phenomenon can be analysed within a theoretical framework of public diplomacy; and in fact a new term, "development diplomacy", emerges as a label for development aid being a specific kind of public diplomacy activity.

Works of number of scholars who reflected on theoretical frameworks of public diplomacy contain elements supporting such an approach, although at first glance these indications might seem scattered (see for example: Melissen, 2005; Snow, Taylor, 2009). There also exists some empirical evidence - or reflection based on analysis of such an evidence - showing the link between extension of development aid and realisation of foreign policy aims. So how exactly can this theoretical construct look like - and what are the practical implications? This article draws on existing works and author's own observations in order to arrive at a more comprehensive picture.

\section{Development Diplomacy as a Part of Public Diplomacy: Theoretical Considerations}

A textbook (Bagiński, Czaplicka, Szczyciński, 2009, p. 12, 129) definition of development aid characterises it as activities consisting of transmission, by society or government of one state, to society of another state, of certain resources, material or immaterial; on terms more favourable than those available on the international market and enabling acceleration of the other state's development. According to these authors, forms of aid can be systematised as follows:

- financial aid: donations, loans, debt relief,

- material aid: consumer goods, investment, food,

- technical aid: training, counselling, expertise.

Public diplomacy can be defined, following a definition coined by Ociepka (2008, p. 12; see also: Snow, Taylor, 2009), as a "two-way, dialogical form of polit- 
ical international communication, directed at the public abroad, realised through the media and direct channels. Its aim is shaping or supporting a positive image of a country and society abroad, including - by influence on public opinion - building of positive attitudes towards the country. Public diplomacy understood in this way is meant to assist in the realisation of aims of given country's policy in the international environment".

Public diplomacy is a foreign policy instrument used especially (but not only) by democratic states. It recognises the growing role played in international relations by international companies, media, non-governmental organisations, and other forms of civil society, including individuals. It develops fast in the information age, together with advancement of mass communication and social media, but certain instruments of public diplomacy are in use since decades - even if so far they were not conceived as part of it.

Recent decades witnessed broadening of the scope of the definition and instruments of public diplomacy well beyond traditional information campaigns or promotion of economy and culture. Several "new", or - rather - newly recognised, elements of (post-Cold War, thus called a "new") public diplomacy have been identified and promoted, such as:

- educational diplomacy - spreading positive knowledge about and attitudes towards a given country through mobility of students and academic professionals (sending them to study or work abroad or accepting foreigners at own universities; promoting own educational system $)^{1}$;

- citizen diplomacy - developing consciousness of own citizens regarding the way in which various forms of their presence abroad and communication with foreign nationals can influence the image of the state abroad (Nakonieczna, 2013; Snow, Taylor, 2009);

- digital diplomacy - this term recognises the opportunity presented by - and a need for an active use of - social media in the daily practice of diplomats, who need to address both internal and external public in order to explain their governments' positions and actions (see for example: USCCenter on Public Diplomacy \& The Netherlands Institute of International Relations 'clingendael', 2014);

${ }^{1}$ For example, in the US, Under Secretary for Public Diplomacy and Public Affairs has educational foreign exchange programmes built into his portfolio of responsibilities (U. S. Department of State). See also: Byrne, Hall, 2011. 
- historical diplomacy - promotion of appropriate aspects of a given country's history and of a preferred historical narrative in order to build a positive image abroad ${ }^{2}$;

- local government diplomacy - public diplomacy activities (economic, cultural, and others) performed by local governments in the course of their relations with entities from abroad (see for example: Skorupska, 2015);

- diaspora diplomacy - engaging nationals living abroad and their associations in promotional activities (Ociepka, 2013);

- social diplomacy - international activities of non-governmental organisations, especially those actively present on the ground in other countries; this type of public diplomacy requires careful balancing as credibility of NGOs can be harmed in cases their independence is questioned (Ociepka, 2013, p. 140-144);

- development diplomacy - process of building of a positive image abroad, bilateral relations and international role and position on the basis of aid transfers aimed at promoting development and wellbeing of developing countries ${ }^{3}$.

The borders between sub-kinds of public diplomacy enumerated above are often blurred. For the sake of this article it needs to be underlined that development diplomacy can frequently be traced under educational diplomacy label, when given country's education and training institutions receive funding aimed at accepting students or professionals coming from developing countries free of charge. In such a case the delineation can be done through analysis of the financial flows (from which country are finances originating?; are they coming from the ministry of education or rather a development agency?) and aims of the training (exchanges that can qualify as development diplomacy aim at transfer of knowledge and know-how towards the less developed nation).

Delineation between development diplomacy and social diplomacy poses interesting questions as well, since many civil society organisations engage in activities abroad that aim at enhancing development. If we assume that development

${ }^{2}$ On the Polish historical diplomacy, see for example the Polish Ministry of Foreign Affairs 2012 Yearly Report on Public Diplomacy; Ociepka, 2013, p. 155-166.

${ }^{3}$ It needs to be highlighted that the term development diplomacy (or sustainable development diplomacy) is sometimes used in order to refer to global diplomacy - international negotiations and meetings engaging states and international organisations - focusing on development related topics. Examples include negotiations on the revision of the Millennium Development Goals or global conferences such as United Nations Conference on Sustainable Development. This understanding of the term is not the subject of this article. On the role of development aid in Polish public diplomacy: Ociepka, 2013, p. 131-140. 
diplomacy stays reserved for governmental agencies (and Official Development Assistance ${ }^{4}$ ), than we can set these two apart through checking the share of public (state) money in the given organisation's projects budget. Nevertheless, even organisations which are fully financed from private sources can certainly influence the image of their country of establishment abroad through the aid they bring - so it would seem inappropriate for the "new diplomacy" theory to a priori exclude them from development diplomacy field. ${ }^{5}$

The existing theoretical sources suggest that in fact development diplomacy should be treated as a fully-fledged part of the new public diplomacy. Development diplomacy can be legitimised as part of it since it often possesses one or many of such typical "new public diplomacy" features as: being carried out not only by the governments but also non-state entities; being based on soft power, two-ways communication, management of (credible) information; and being both short- and long-term oriented ${ }^{6}$.

What is more, out of the three theoretical dimensions in which public diplomacy is being realised - that is: information management, strategic communication, and relationship building - development diplomacy can often be conceived as belonging to the third one: the relationship building. Or yet within another theoretical division of public diplomacy, this time into two types: informative and relational - to the second one, along with programmes of cultural, educational or scientific exchanges. The relational dimension or type is believed to be the most long-term and extending beyond one-sided presentation, instead actively engaging both sides (Ociepka, 2008; Ociepka, 2013; see also Snow, Taylor, 2009).

"Public diplomacy encompasses all actions of the state or non-state actors which contribute to maintenance and promotion of the soft power of this given state" (Batora, 2006, cited in: Gilboa's subchapter in Ociepka, 2008, p. 42). Soft power refers to the use of power resources in an indirect and non-compulsory way. Joseph S. Nye junior presented this term initially in a book Bound to Lead: The Changing Nature of American Power (1990) and developed it later on, inter alia, in a book Soft Power. The Means to Success in World Politics (2004). Here he pointed out that soft power means the ability to reach aims thanks to state's attractiveness,

${ }^{4}$ Term used by the Organisation for Economic Cooperation and Development for the sake of accounting for each donor's amount of aid emerging from governmental sources.

${ }^{5}$ Pragmatic approach requires that these borders are never set in stone. It can be observed that in Ociepka's (2013) work, two separate chapters deal, respectively, with the role of development aid and the role of non-governmental organisations, but the latter chapter deals inter alia with organisations providing aid.

${ }^{6}$ List of features based on Gilboa, Dyplomacja w epoce informacji, in: Ociepka 2008, p. 41. 
political ideals, and policy. It is based on the ability to shape the preferences of others and to attract. Soft power resources are those which cause such an attraction, but political results are never guaranteed (Nye, 2007).

Nye did not set out a comprehensive theory of soft power, while focusing on practical side of soft power in the case of the United States. After his initial publication, he himself as well as numerous other scholars reflected on the elements constituting soft power and the nature of its impact. Thus there exists a spectrum of varied approaches, which also differ in their attitude to development aid as one resources of soft power.

In Soft Power. The Means... development aid is not mentioned directly as an element of soft power. It is rather classified under economic power, together with sanctions and bribes. Nevertheless Nye (2007) often mentions, within the concept of soft power, the practice of admission of foreign students (which can constitute a form of development aid) and even refers directly to development aid as serving global public good, or in the context of measuring soft power. In his later work, The Future of Power (2011), Nye on the one hand develops discussion on financial aid as a form of economic power, while on the other hand underlines that economic resources are the sources of both hard and soft power. He also locates aid programmes (together with, inter alia, student exchange programmes) in the context of soft power generation ${ }^{7}$. It is worth underlining that although Nye concentrates on financial transfers, development aid can also take shape of transfer of technologies and other forms of know-how sharing. The aid can furthermore be motivated rather by social model from which it emerges than purely political motives. Thus development aid, although in most cases based on economic power, can be accepted as a resource for soft power understood in its relational sense.

Also in The Future of Power, Nye reflects on the effectiveness of aid in terms of its impact on soft power. He points out to limited effectiveness in the cases when aid endangers recipient's internal relations of power or when it is conditional. Positive effects can be observed in cases of small projects, implemented within conditions of agreement and participation of a local population. Elsewhere, Nye underlines that actions involving two-side communication are more effective as a part of public diplomacy efforts than those which have a nature of a one-sided message. These observations can be extrapolated in order to reflect on effectiveness of various kinds of aid (for example, financial transfers vs. knowledge transfer) in the contexts of soft power and public diplomacy.

\footnotetext{
7 See also Joseph S. Nye, The War on Soft Power, Foreign Policy, 12.04.2011.
} 
Development aid is also included in classifications of elements of soft power proposed by other authors, for example, as a "form of exposing soft power" (Potocki, Miłoszewska, 2010, p.4). It is included in The New Persuaders reports, prepared by Jonathan McClory for the British Institute for Government, which contain proposals for a soft power index. Here, foreign development aid is located as one of indicators under sub-index "diplomacy". Similarly, development aid is taken into account in the Elcano Institute Global Presence Index as well as the "Soft Power 30" ranking prepared by Portland Communications.

Development aid is closely linked to soft power because: it shapes positive attitudes, including gratitude and admiration toward the donor; it serves transmission of information about the donor and the values it stands for; it raises interest in the donor country; and it is also often based on non-material resources that a donor state has to offer, such as knowledge and know-how: achievements and discoveries in science, technologies, environment, health, political system, social life, and so on.

To summarise, the role of development aid in (new) public diplomacy is multidimensional, as aid constitutes a soft power resource for public diplomacy in itself, but it also serves employment of other soft power resources in the service of public diplomacy. Since this influence is mediated through soft power, the phenomenon of development diplomacy can take place even if development aid is not formally treated as part of public diplomacy of a given state. Furthermore, the more aid is given in a form that develops positive, mutual and symmetric relationships, the more it is conducive to enhancing donor's soft power and supporting its public diplomacy.

\section{Development Diplomacy and Foreign Policy Aims: Practical Approaches}

Foreign policy, in general terms, can be defined as a "dynamic process of formulation and realization of national interests and policy aims in a polycentric international environment" (Łoś-Nowak, 2008, p. 77). This process has three phases: identification of needs, interests and aims; formulation of interests of state and nation; and policy implementation. According to the realistic approach in international relations' theory, it is only the national interest that determines foreign policy aims, methods, and measures. On the other hand, neo-liberal approach accepts that international environment and public opinion can exert certain influence on national interest. Moreover, it recognises cooperative forms of interest, based on 
universal values (Łoś-Nowak, 2011). It is within this framework that development policy - being a recognized or implicit part of public diplomacy - can be analysed in relation to foreign policy aims. This analysis can be done through an overview of a limited - by the scope of this article - number of examples answering the following questions: is development diplomacy enshrined as a part of soft power and/ /or public diplomacy within government structures or in policy documents?; and is there any research done regarding practicalities of employment of development diplomacy in realisation of foreign policy aims?

The answer to the first question is generally negative, as development aid requires vast and specialised, and thus separate administration. A common practice among donor states is to have a department within foreign ministry dedicated to foreign aid programming (including "development diplomacy", understood as participation in global forums and negotiations regarding sustainable development), which is often assisted by an agency responsible for implementation of aid programmes. Departments responsible for public diplomacy usually concentrate on communication and branding campaigns, which, among other sources, can be - and often are - based on information about actions undertaken by the sections of government responsible for development aid. As indicated, administrative divisions do not preclude possibility for cooperation and conversion in the course of policy practice. Certain government levels or government related documents confirm the fact that in practice a link between development aid and public diplomacy, soft power or foreign policy aims is made ${ }^{8}$. Analysis of structures (including outposts abroad) and realities of working practice of the various donors goes beyond the scope of this article. By a way of example, basic information can be presented here on some of the countries of interest:

- Within the United States Department of State, a separate State Secretary directly oversees the United States Agency for International Development (USAID), while Under Secretary for Public Diplomacy and Public Affairs heads sections for Education and Cultural Affairs, International Information Programs and Public Affairs. Popularisation of development aid is not directly mentioned in the mandate of the Under Secretary (U. S. Department of State Diplomacy in Action website) ${ }^{9}$. Yet Under Secretary oversees the Bureau of Public Affairs, within which USAID Press office is situated

\footnotetext{
${ }^{8}$ Such as the Polish Ministry of Foreign Affairs.

9 "The Under Secretary for Public Diplomacy and Public Affairs Richard Stengel leads America's public diplomacy outreach, which includes communications with international audiences, cultural programming, academic grants, educational exchanges, international visitor programs, and US Government efforts to confront ideological support for terrorism”.
} 
- although its activities are mainly inward-oriented (USAID Press website). The shock of September 11, 2011 terrorist attacks and the ensuing wars in Afghanistan and Iraq opened up a vast debate in the U.S. regarding its public diplomacy, including positioning of development aid as a resource for so called "winning hearts and minds", and "a key instrument of foreign policy in the coming decades" (USAID 2002; see also Hackbarth, 2008) ${ }^{10}$.

- In the United Kingdom, the structures include a ministerial level Department for International Development (DFID), working directly with developing countries (Department for International Development homepage) and, on the public diplomacy side, three main institutions: Foreign and Commonwealth Office (FCO; foreign ministry), the British Council (BC; British Council website), and the BBC World Service - all of them being conscious and active public diplomacy actors. In particular, FCO positions a web-link dedicated to the Official Development Assistance at the upper front of its website. The activities of the British Council go far beyond its main "culture institute" type of objectives related to promotion of cultural cooperation and language skills. Inter alia, the BC engages extensively in development aid as it "delivers projects that contribute to the UK's international development goals" (British Council website). It can be observed that the $\mathrm{BC}$ serves as a "soft power" agency, exercising manifold new public diplomacy approaches, directly on the ground in other countries, while also engaging in a broader reflection on public diplomacy and soft power issues ${ }^{11}$.

- In Poland, Department of Development Cooperation of the Ministry of Foreign Affairs is assisted by an agency called Polish Aid and a foundation called Solidarity Fund PL. The Ministry's Department of Public and Cultural Diplomacy explicitly recognises various new diplomacy instruments, including the role of development aid in the process of fulfilment of its mission (Polish Aid website; Polish Ministry of Foreign Affairs website; Solidarity Fund PL website) ${ }^{12}$.

${ }^{10}$ Critical reflection regards also earlier experiences, starting from post World War Two aid to Europe (Snow, Taylor, 2009).

${ }^{11}$ For more on the case of the British Council, its relations with the government, and on the specific interest the British Parliament displays towards public diplomacy, see for example House of Commons Foreign Affairs Committee Public Diplomacy Third Report of Session 2005-06; or Select Committee on Soft Power and the UK's Influence, 2014.

12 Some public diplomacy roles are also entrusted to other Departments, such as the Department for Cooperation with Polish Diaspora and Poles Abroad. 
- The European Union can also be taken into account when considering development diplomacy issues - as the biggest institutional donor, as well as major "soft" and "normative" power. Its executive structures to a large extent mirror the ones of the member states. The European Commission plays the greatest role from among the Union's institutions as it implements the EU development aid through Directorate-General for International Cooperation and Development (DG DEVCO). On the other hand, Commission's public diplomacy activities are carried out by Directorate-General Communication (DG COMM) as well as DG DEVCO's own activities. DG COMM "provides corporate communication tools and expertise to other Directorate-Generals for their communication strategies and activities" (DG COMM), concentrating its activities on main political issues (DG COMM website). DG DEVCO launches own public diplomacy initiatives (DG DEVCO website).

Attention shall also be drown to the national legislature regulating development aid, as it often contains elements closely connected to public diplomacy and image building, or references to foreign policy aims. One such example can be declarations on values guiding provision of aid, which include:

- Canada: "Canadian values means, amongst others, values of global citizenship, equity and environmental sustainability (...) The purpose of this Act is to ensure that all Canadian official development assistance abroad is provided with a central focus on poverty reduction and in a manner that is consistent with Canadian values, Canadian foreign policy (...). Canadian official development assistance abroad shall be defined exclusively with regard to these values" (Canada, The Minister of Justice, 2015).

- Japan: "Such efforts will in turn benefit Japan itself in a number of ways, including by promoting friendly relations and people-to-people exchanges with other countries, and by strengthening Japan's standing in the international arena" (Government of Japan Ministry of Foreign Affairs Economic Co-operation Bureau, 2003).

- Iceland: "Icelandic development cooperation reflects values that Icelandic society holds high: respect for democracy and human rights, human diversity, tolerance, justice and solidarity" (Icelandic Ministry of Foreign Affairs, 2011).

- The European Union: "EU partnership and dialogue with third countries will promote common values of: respect for human rights, fundamental freedoms, peace, democracy, good governance, gender equality, the rule of law, solidarity and justice. The EU is strongly committed to effective multilateralism whereby all the world's nations share responsibility for development" (European Union institutions, 2006). 
There exists a limited number of research aimed at checking practical results of development aid from the point of view of donors' interests in the field of international relations. The difficulty in such assessments results from the fact that political relations between donor and recipient nations are determined by manifold and deeply embedded factors, by far not only by aid programmes - especially in the cases of relationships between former colonisers and former colonies. In order to arrive at a more objective assessment, the choice is often made to check political results of aid given by donors having no colonial past in relationship to the beneficiaries chosen; and to check political influence of aid as manifested in the relationship with a third party, especially in the form of patterns of voting at the United Nations General Assembly (UNGA). Research on specific cases of influence of development aid on bilateral and regional political dynamics can be a point of departure for answering the question of political results of aid; one specific example is also described beneath in more detail.

Alberto Alesina and David Dollar (1998) maintain that provision of development aid is conditioned mainly upon political and strategic reasons (colonial past, political alliances, ongoing democratisation), far more than by economic needs or policy performance of the beneficiary (which also determines limited effectiveness of aid). Their analysis of UNGA voting behaviours of beneficiary states showed that they are usually inclined to vote in line with interests of the donors. Nevertheless, rather than concluding that "aid buys votes", the authors suggest that this compatibility of votes results rather from an existing alliance between beneficiary and the donor. This conclusion is however based mainly on an assumption that UNGA votes are on the rule "fairly irrelevant" to the interests of the majority of countries voting.

Another study has been carried out by Dreher, Nunnenkamp, and Thiele (2006) and regarded relationship between aid given by the US and behaviour of 143 beneficiary countries in UNGA in the years 1973-2002. Authors claim that even "irrelevant" UNGA votes were treated by the American officials as an important factor affecting bilateral relations, for example as an indicator of given country's values. These authors take into account variations of forms of aid, concluding that general budgetary support and untied aid grants contribute to greater compatibility between beneficiaries' votes at UNGA and US interests. However, after carrying out a similar analysis for G7 countries they did not arrive at a same conclusion, which also backs assumption that political motives influence heavily on the distribution of US Aid ${ }^{13}$.

13 This work contains also an overview of other research done on relationship between aid and voting. 
T.Y. Wang (1999) argues that "UNGA votes indicator" should be nuanced by choosing only the votes that are deemed to be "significant" - from the point of view of donor's political interest - and that the analysis should also take into account the share of given donor's aid in the overall volume of aid received by a given beneficiary. Wang's research testifies to the thesis that although aid as such is not highly correlated with beneficiaries' voting on issues of key importance to the US, the variations (increase or decrease) of US aid level can be effectively used to influence developing countries' voting patterns.

A particular example of a development aid programme which brought concrete foreign policy benefits is the case of Israeli development assistance to Sub-Saharan Africa countries which lasted for over almost two decades, between 1956 and $1973^{14}$. The aid programme was based on Israeli achievements in the areas such as agriculture, reforestation, water management but also those of state- and nation building, education and healthcare. These achievements emerged in conditions such as climate, population growth or social challenges - in many ways similar to those in the newly independent African countries. On the Israeli side there was a strong willingness to share own know-how and experiences. This willingness resulted from the Jewish ethos (especially the "repair the world" commitment) and the ethos of Zionism. Already Theodor Herzl underlined the need to help the African peoples and Labour Zionism (which dominated Israeli politics in the first decades of its existence) underlined the need for solutions that would make the world a fairer place, while seeing Israel as paving a "third path" between socialism and capitalism. The shape of the Israeli aid programme for Sub-Saharan Africa countries resulted also from the fact that Israel, although developing fast, was still not an affluent country: thus the programme did not entail transfers of money, concentrating instead on various forms of technical aid - training, counselling, expertise transfer - which joined thousands of African nationals and Israeli experts either on-the-spot in Africa or in the Israeli institutions offering training.

Hence the Israeli programme had all the features qualifying it as a development diplomacy model: it was based on donor's own soft power resources, it represented donor's values, it emerged in dialogue with the beneficiaries' needs (and out of their feeling of the similarity of fate) and involved people-to-people relationship building (with Israeli experts perceived as modest and committed). The programme also had a strong foreign policy dimension: although aid was not

${ }^{14}$ Author's own conclusions drawn in the process of work on a doctoral thesis on Israeli development aid to Sub-Saharan Africa countries as an element of Israeli soft power, based on, inter alia: Olo, 1988; Peters, 1992; Decalo, 1998. 
conditioned upon beneficiaries' diplomatic behaviours, it emerged in the context of a search for new allies, in the face of both Eastern and Western blocks ambivalent attitude towards the young state, surrounded by hostile neighbours. In fact, development aid programme formed a backbone of rapidly developing bilateral relationships between Israel and more than 30 Sub-Saharan countries. Diplomatic relations were formalised shortly after successful decolonisation. African diplomatic posts were in many cases located in (divided) Jerusalem, thus recognising it as a rightful capital of Israel. High level state visits were frequent. What is more, throughout the 1960s, African countries used to block anti-Israeli measures that the Arab states tried to adopt at the Organization of African Unity. They also adopted more pro-Israeli than pro-Arab attitudes at the United Nations General Assembly, as exemplified by their patterns of voting on the resolutions that followed the 1967 Israeli-Arab war.

However, this relationship, to a large extent based on soft power, did not stand the test of geo-political realities, such as: consequences of 1973 Israeli-Arab war (both political and economic - high oil prices); ideological, political and economic pressure of Arab states; requirements of Arab unity; internal politics of African states. As a result, all but three Sub-Saharan states severed relations with Israel and the Israeli side abandoned its aid programme. Nevertheless, severing of relations with Israel was met with discontent in some African countries. Paradoxically, economic relations had been developing fast in the ensuing years and once geopolitical realities allowed (with the Israeli-Egyptian peace accord in 1979 and Israeli-Arab peace process in the 1990s) - relations were restored. This turn of events might be treated as testifying to the long-term positive impacts of aid programme on mutual relations.

As Ociepka (2013, p. 140) observed, positive impacts of development aid on the perception of the donor country are dependent upon place and timing of the development aid deployment, as well as on the political culture of the recipient country. The above analysis of practical side of employment of development aid as part of diplomacy testifies to the fact that it brings limited results in terms of realisation of the aims of foreign policy. This is mainly because effectiveness of development aid as an instrument of diplomacy is highly dependent upon other factors, usually belonging to the "hard power" realm - geostrategic considerations, such as regional power balance, economical interests - or to the realm of internal politics of the beneficiary state. It may also be hard to distinguish between political results brought by development diplomacy and those resulting from other factors, or evaluate the share of development aid in the overall positive result. 


\section{Conclusions}

The guiding assumption is that conscious development diplomacy is born at the very moment it is recognised as a part of foreign policy in the context of public diplomacy and/or soft power. The theoretical and practical considerations elaborated upon in this article testify, on the one hand, to the significant and multidimensional potential of development aid as a part of public diplomacy, but on the other hand - to the difficulties in its practical employment with a view to realizing foreign policy aims. It is in this context that some conclusions can be drown.

Development diplomacy, in order to function in practice as a part of new public diplomacy, should preferably be assisted by other public diplomacy instruments. In relation to beneficiary countries, traditional information campaigns can be of help, however they have to be carried out very carefully, in order to avoid propaganda and to build trust, rather than undermine the image of a "disinterested" donor. "New public diplomacy" instruments, such as social diplomacy (involvement of NGOs) or students' and professionals' exchanges, can be employed, as a part of, or apart from development programmes, as a measure for spreading knowledge about a donor country. Form of aid is also important in this context, as direct contacts between donor's and beneficiary's nationals, if carried out properly, can be conducive to mutual learning and building of a positive image. Thus forms of aid such as training, study visits, acceptance of students, on-the-spot consultations or know-how transfer, as well as small-scale projects well embedded in local community, seem to be most promising in terms of converging aims related to development with the ones of public diplomacy (and also requiring less promotional "assistance" by other public diplomacy measures). The bottom-up effect of such endeavours, among the other factors, will depend inter alia on the political system (i.e. presence and quality of democracy) of the beneficiary state.

This leads to another conclusion: that for development diplomacy to work it has to be consciously intertwined in the bilateral relations with a given beneficiary. A general strategy can be elaborated, but concrete solutions shall be tailored for each country specifically, and in some cases - also bearing in mind internal divisions in the recipient country's society. Such individual solutions should take into account history of bilateral relations so far, as well as political, economic, and cultural dimensions of bilateral relations as well as beneficiary's internal situation.

In relation to other countries of the world, employment of assistant public diplomacy instruments, such as promotional campaigns, in order to promote the scale and effectiveness of development aid with an aim of building up a positive image beyond the beneficiary countries, seems to be less challenging, although the 
results might depend strongly on non-related political factors. In such efforts, not only international information campaigns can be of use, but also informing own nationals and diasporas, who can in turn popularise this knowledge in the course of their encounters with foreign nationals.

Successful development diplomacy requires also a proper reflection on the donor's soft power resources, on how they might reply to the beneficiaries' needs and also serve post factum promotional campaigns. This seems an obvious exercise of every donor deploying certain development aid to a given country, yet reflection from the point of view of potential public diplomacy benefits could bring in new ideas.

Development diplomacy as a conscious policy also requires clarity regarding its aims. Obviously - aside from the development aims - they need to locate themselves within public diplomacy aims; development diplomacy can promote an image of a state as a donor and promote its' other soft power resources. Here however a tension is born between altruistic and egoistic motivations for aid giving. While on the surface, public diplomacy looks "innocent", soft power remains a sort of power and in the end, both concepts serve foreign policy interests - economic, strategic or security. These interests are concrete, realistic, mundane, and result from some sort of a power balance, even if per se they are not directed against any other actor of international relations. It doesn't seem however too productive to try to distil purely "disinterested" aid and mark everything else as "politically motivated". Ultimately, in the age of globalisation, reducing poverty and desperation in other countries always benefits the donor, for example through reducing migrant pressure or potential security threats. The fact that development aid of such donors as Sweden, the Netherlands, Norway, Denmark or Finland is motivated by clearly altruistic reasons, does not contradict the fact that for such small and medium size, although affluent countries, launching foreign aid programmes is usually connected to undertaking certain moral standing, which constitutes part of conscious formation of own role in the international system (Ociepka, 2013, p. 132). In a similar way, promotion of own achievements through exporting them abroad in the form of aid constitutes a solution for countries which otherwise do not have potential for large scale aid programmes, as Israel or Poland. Thus relational aspect of development diplomacy truly works for both sides - the one benefiting from the aid received, the other reaping fruit of aid given in the form of improved image and possible benefits in other spheres (political, economic) ${ }^{15}$.

15 In that way, development aid becomes an instrument of "smart power". For more on this and for analysis of the case of the Polish development aid, see Kugiel, 2013. On Polish aid as a part of public diplomacy, see also Ociepka, 2013. 


\section{References:}

Alesina, A., Dollar, D. (1998). Who Gives Foreign Aid to Whom and Why. Journal of Economic Growth, 5 (1), 33-63. Retrieved from: http://nrs.harvard.edu/urn-3:HUL. InstRepos:4553020.

Bagiński, P., Czaplicka, K., Szczyciński, J. (2009). Międzynarodowa wspótpraca na rzecz rozwoju. Ewolucja, stan obecny i perspektywy. Warszawa: Polskie Wydawnictwo Ekonomiczne.

British Council website. Our organisation. Retrieved from: http://www.britishcouncil.org/ organisation.

British Council website. Official development assistance. Retrieved from: http://www.britishcouncil.org/organisation/transparency/official-development-assistance.

Byrne, C., Hall, R. (2011). Australia's International Education as Public Diplomacy: Soft Power Potential. The Discussions Papers in Diplomacy. Retrieved from: http://www.clingendael.nl/sites/default/files/20110700_cdsp_discussion_paper_cbryne_rhall.pdf.

Decalo, S. (1998). Israel and Africa. Forty Years 1956-1996. Florida Academic Press

Department for International Development. About Us. Retrieved from: https://www.gov. uk/government/organisations/department-for-international-development/about.

Directorate General Communication. What we Do. Retrieved from: http://ec.europa.eu/ dgs/communication/about/what_we_do/index_en.htm.

Directorate General International Cooperation and Development. Projects and Results. Retrieved from: http://ec.europa.eu/europeaid/projects-results-0_en.

Dreher, A., Nunnenkamp, P., Thiele, R. (2006). Does US Aid Buy UN General Assembly Votes? A Disaggregated Analysis. Retrieved from: https://www.ifw-kiel.de/ifw_members/global-images/kap1275.pdf.

Elcano Global Presence Report 2014. (2014). Retrieved from: http://www.globalpresence. realinstitutoelcano.org/en/data/Global_Presence_2014.pdf.

Foreign Aid in the National Interest Promoting Freedom, Security, and Opportunity. (2002). Retrieved from: http://www.au.af.mil/au/awc/awcgate/usaid/foreign_aid_in_the_national_interest-full.pdf.

Foreign and Commonwealth Office. Retrieved from: https://www.gov.uk/government/organisations/foreign-commonwealth-office.

Hackbarth, J.R.(2008). Soft Power and Smart Power in Africa. Retrieved from: www.dtic. $\mathrm{mil} /$ cgi-bin/GetTRDoc?AD=ADA517405.

House of Commons Foreign Affairs Committee Public Diplomacy Third Report of Session 2005-06. (2006). Retrieved from: http://www.publications.parliament.uk/pa/ $\mathrm{cm} 200506 / \mathrm{cmselect} / \mathrm{cmfaff} / 903 / 903 . p d f$.

Japan's Official Development Assistance Charter. (2003). Retrieved from: http://www.mofa. go.jp/policy/oda/reform/revision0308.pdf.

Joint statement by the Council and the Representatives of the Governments of the Member States Meeting within the Council, the European Parliament and the Commission on European Union Development Policy: 'The European Consensus'. (2006). Retrieved from: http://eur-lex.europa.eu/LexUriServ/LexUriServ.do?uri=OJ\%3AC\%3A2006\%3A046 $\% 3 \mathrm{~A} 0001 \% 3 \mathrm{~A} 0019 \% 3 \mathrm{AEN} \% 3 \mathrm{APDF}$ 
Kugiel, P. (2013). Development Cooperation as a Smart-Power Tool: Lessons for Poland. The Polish Institute of International Affairs Bulletin, 132 (585). Retrieved from: https:// www.pism.pl/files/?id_plik=15686.

McClory, J. (2010). The New Persuaders. Institute for Government/Monocle.

McClory, J. (2011). The New Persuaders II. Institute for Government/Monocle.

McClory, J. (2012). The New Persuaders III. Institute for Government/Monocle.

Melissen, J. (ed.). (2005). The New Public Diplomacy. Soft Power in International Relations. Retrieved from: http://culturaldiplomacy.org/academy/pdf/research/books/soft_power/The_New_Public_Diplomacy.pdf.

Nakonieczna, J. (2013). Kultura w tworzeniu reputacji państwa. In: H. Schreiber, G. Michałowska (eds.), Kultura w stosunkach międzynarodowych, Tom 1: Zwrot kulturowy. Warszawa: Wydawnictwo Uniwersytetu Warszawskiego.

Nye J.S. (2007). Soft Power. Jak osiagnąćsukces w polityceświatowej. Warszawa: Wydawnictwa Akademickie i Profesjonalne.

Nye J.S. Jr. (2011). The Future of Power. Public Affairs.

Ociepka, B. (ed.). (2008). Dyplomacja publiczna. Wrocław: Wydawnictwo Uniwersytetu Wrocławskiego.

Ociepka, B. (2013). Miękka sita i dyplomacja publiczna Polski. Wydawnictwo Naukowe Scholar Sp. z o.o.

Olo, O. (1988). Africa and Israel: Relations in Perspective. Westview Press.

Official Development Assistance - Definition and Coverage. Retrieved from: http://www.oecd. org/dac/stats/officialdevelopmentassistancedefinitionandcoverage.htm\#Definition.

Official Development Assistance Accountability (2015). Retrieved from: http://laws-lois.justice.gc.ca/PDF/O-2.8.pdf.

Peters, J. (1992). Israel and Africa. The Problematic Friendship. I.B. Tauris.

Polish Aid website. About Polish Aid. Retrieved from: https://www.polskapomoc.gov.pl/ Mission,statement,204.html.

Polish Ministry of Foreign Affairs 2012 Yearly Report on Public Diplomacy. Retrieved from: https://www.msz.gov.pl/resource/019d6590-c271-4462-9f3d-09cd5410795b:JCR.

Polish Ministry of Foreign Affairs website. About Public Diplomacy. Retrieved from: http://www.msz.gov.pl/en/foreign_policy/public_diplomacy/about_public_diplomacy/about_public_diplomacy.

Portland Communications website. Retrieved from: http://www.portland-communications.com/.

Potocki, R., Miłoszewska, D. Rola soft power w środowisku międzynarodowym. Retrieved from: https://repozytorium.amu.edu.pl/jspui/bitstream/10593/966/1/Soft\%20power.pdf.

Select Committee on Soft Power and the UK's Influence - First Report Persuasion and Power in the Modern World. (2014). Retrieved from: http://www.publications.parliament.uk/ pa/ld201314/ldselect/ldsoftpower/150/15002.htm.

Skorupska, A. (2015). The Role of Local Governments in National Foreign Policy in Poland. Retrieved from: http://www.pism.pl/files/?id_plik=19516.

Snow, N., Taylor, P. (eds.). (2009). Routledge Handbook of Public Diplomacy. Retrieved from: http://bdinstitute.org/wp-content/uploads/2012/02/A1-handbookofpublicdiplomacy.pdf. 
Solidarity Fund PL website. Solidarity Fund PL. Retrieved from: http://www.solidarityfund.pl/en/fundacja1/o-fundacji.

Strategy for Iceland's International Development Cooperation, 2011-2014. Retrieved from: http://www.mfa.is/media/throunarsamvinna/Strategy-for-Icelands-Development-Cooperation-2011-2014_EN.pdf.

USCCenter on Public Diplomacy \& The Netherlands Institute of International Relations 'clingendael', 2014. The Digital Diplomacy Bibliography. Retrieved from: http:// uscpublicdiplomacy.org/sites/uscpublicdiplomacy.org/files/useruploads/u25898/Digital_Diplomacy_Bibliography_2014_CLI-CPD.pdf.

U. S. Department of State, Diplomacy in Action. Under Secretary for Public Diplomacy and Public Affairs. Retrieved from: http://www.state.gov/r/.

Wang, T.Y. (1999). U.S. Foreign Aid and U.N. Voting: An Analysis of Important Issues, p. 199-210. Retrieved from: http://web.stanford.edu/class/ips216/Readings/wang_99. pdf. 